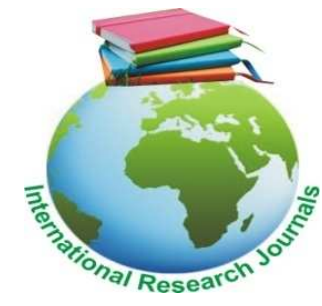

International Research Journal of Agricultural Science and Soil Science (ISSN: 2251-0044) Vol. 7(4) pp. 051-057, December, 2017

Available online http://www.interesjournals.org/lRJAS

DOI: http:/dx.doi.org/10.14303/irjas.2015.027

Copyright (C) 2017 International Research Journals

Full Length Research Paper

\title{
Relationship between soil properties, $p$ sorption characteristics and fertilizer $p$ for optimum yield of soybean (Glycine Max (L.) Merr.) on some inceptisols in Benue
}

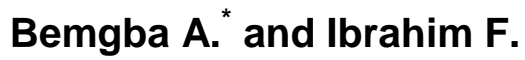 \\ Department of Soil Science College of Agronomy, University of Agriculture, Makurdi- Nigeria \\ 'Correspondence author's Email:bemgbanjembe@gmail.com
}

\begin{abstract}
Phosphorus (P) sorption influences $P$ requirement of Nigerian soils. Four Inceptisols in Benue state were therefore used to examine the influence of soil properties on sorption indices and yield of soybean. Soil inorganic $P$ was fractionated using standard procedures. Sorption characteristics were determined in $0.01 \mathrm{M} \mathrm{CaCl}_{2}$ solutions of various $\mathbf{P}$ concentrations. For each soil, the amounts of $\mathbf{P}$ that gave $0.025,0.05,0.075,0.100,0.125,0.150,0.175,0.200,0.225,0.250 \mathrm{mg} / \mathrm{kg}$ solution concentration and the buffering capacity were estimated from adsorption curves. In the greenhouse, $4 \mathrm{~kg}$ of soil from each location was placed in plastic pots. Amount of $\mathrm{P}$ estimated from sorption study was added as $\mathrm{KH}_{2} \mathrm{PO}_{4}$ The treatments were laid out in Randomized Complete Block Design (RCBD) and soybean seed variety (TGx 1448-2E) was planted and observed to maturity. At harvest, the shoot was dried, weighed, milled and digested in a 4:1 $\mathrm{HNO}_{3}: \mathrm{HClO}_{4}$ mixture and analyzed for $\mathrm{P}$. Optimum solution $\mathrm{P}$ concentration (SPC) was determined for each soil in relation to yield. The $P$ adsorption capacities $(K)$ of the soils related significantly to $P$ in biomass $(r=0.661)$. High grain yield (t/ha) was obtained at $0.025 \mathrm{mg} \mathrm{P} / \mathrm{kg} \mathrm{SPC}$ in Abeda-Mbadyul (8.5) and Otobi-Akpa (12.5) while 5.4 t/ha was obtained in Tor-donga and 4.1 t/hain Odobaat $0.10 \mathrm{mg} \mathrm{P} / \mathrm{kg} \mathrm{SPC}$ in the green house experiment. Slightly higher grain yield was obtained at Otobi (6.4t/ha) in the field trial than the estimated SPC values. Buffering capacities of soils varied and related significantly with seed weight $(r=0.605)$ and $P$ in biomass $(r=-0.667)$. Consequently, Odoba would require highest $P$ fertilizer application (604.84 Kg P/ha), Tor-Donga (112.31), Abeda-Mbadyul (105.93) and Otobi (33.18)
\end{abstract}

Keywords: Phosphorus, Sorption, Inceptisols, Soybean, Relationships, Yield

\section{INTRODUCTION}

Phosphorus $(P)$ sorption characteristics have not been widely used for routine diagnosis of crop requirements due mainly to the number of analyses required to characterize the sorption capacity of a soil (Adetunji, 1995). The high capacity of tropical soils to fix soluble $P$ has contributed to a very low level of $P$ in solution (Anyanduba and Adepetu, 1983). The rate and strength of sorption, as well as the sorption capacity of a soil are dependent on the soil properties that affect the absorption and adsorption of $\mathrm{P}$. Texture is one such property. Fine textured soils, those with a high percentage of clay, have a greater surface area and thus greater reactivity. It has been observed (Adepetu, 1981; Adepoju, 1993; Adetunji, 1995; Anyanduba and Adepetu, 1983) that $P$ sorption influences $P$ requirement of Nigerian soils. Dalal and Hallsworth (1976) have also shown that $\mathrm{P}$ sorption capacity is a principal factor regulating solution $\mathrm{P}$ concentration.

In Nigeria, an estimated 50,000 hectares of Soybean, Glycine $\max (L)$ Merr.is cultivated annually, most of this 
052 Int. Res. J. Agric. Sci. Soil Sci.

Table 1: Classification of Sampled Sites

\begin{tabular}{lcc}
\hline S/NO & LOCATION & SOIL CLASS \\
\hline 1. & Abeda-Mbadyul & $\begin{array}{l}\text { Oxicustropept (USDA) } \\
\text { Eutriccambisol (FAO) } \\
\text { Oxicustropept (USDA) } \\
\text { Eutriccambisol (FAO) }\end{array}$ \\
3. & Otobi, Akpa & $\begin{array}{c}\text { Estoxicdystropept (USDA) } \\
\text { Ferraliccambisol (FAO) }\end{array}$ \\
4. & Tor Donga & Oxicustropept (USDA) \\
& Odoba & Eutriccambisol (FAO) \\
\hline
\end{tabular}

Source: Federal Department of Agricultural Land Resources (FDALR, 1990)

being in Benue State (Aduayi et al., eds. 2002). Farmers' yields average $300-1,030 \mathrm{~kg} \mathrm{ha}^{-1}$ of threshold grain. Under research conditions, yields of over $3000 \mathrm{~kg} \mathrm{ha}^{-1}$ have been recorded. Higher yield values and better quality of the crop are probable if phosphate interaction in soils is well understood and properly managed as $P$ is the limiting nutrient element for the production of this crop.

This study was therefore undertaken to determine: The relationships between soil properties and $\mathrm{P}$ sorption characteristics in the soils under study;

The effect of these properties on soybean yield in the soils;

The effect of these properties on $P$ fertilizer need on these soils for soybean production.

\section{MATERIALS AND METHODS}

The study involved laboratory, pot and field experiments. The laboratory experiment consisted of routine soil analysis, phosphorus fractionation study, total oxides and $P$ sorption experiment.

Surface soil samples $(0-20 \mathrm{~cm})$ were collected from four bench mark soils in Benue State earlier classified as Inceptisols (FDALR, 1990) as shown in Table 1. All the sampled locations fall within the southern Guinea savannah zone of Nigeria. The samples were air dried and passed through a $2 \mathrm{~mm}$ sieve for laboratory studies and pot experiment. Soil $\mathrm{pH}$ was determined by the glass electrode in a 1:2 soil: water ratio and in a $1: 1$ soil: $\mathrm{KCl}$ ratio suspensions. Particle size analysis was determined by the hydrometer method of Bouyoucos, (1951), organic carbon by the chromic acid oxidation procedure of Walkley and Black, (1934). Exchangeable bases by the neutral ammonium acetate saturation. Sodium and $\mathrm{K}$ in the extracts were determined by flame photometry while $\mathrm{Ca}$ and $\mathrm{Mg}$ were determined by Atomic Absorption Spectrophotometer (AAS). Exchange acidity by the $1 \mathrm{M}$ $\mathrm{KCl}$ extraction and $0.01 \mathrm{M} \mathrm{NaOH}$ titration. Nitrogen in the samples was determined by the macro- Kjeldahl method.

\section{Phosphorus Fractionation}

Phosphorus fractionation was done by the modified procedure of (Chang and Jackson, 1957) as modified by (Peterson and Corey, 1966) and reported by (Page et al., 1982). Total and organic $P$ was determined by the $\mathrm{NaOH}$ digestion method (Mehra et al., 1954). Available $P$ was extracted by $0.5 \mathrm{M} \mathrm{NaHCO}_{3}$ buffered at $\mathrm{pH} 8.5$, (Olsen et al., 1954) and by $0.03 \mathrm{M} \mathrm{NH}_{4} \mathrm{~F}+0.025 \mathrm{M} \mathrm{HCl}$,(Bray and Kutz, 1945). Phosphorus in the extracts was determined colorimetrically by the Ascorbic acid method of (Murphy and Riley, 1962) as modified by (Watanabe and Olsen, 1965) and reported by (Page et al., 1982).

Free $\mathrm{Fe}$ and $\mathrm{Al}$ oxides (Total oxides) were extracted by the citrate dithionate-bicarbonate method, (Mebra and Jackson,1960). Iron and aluminum oxides in the extracts were determined with an atomic absorption spectrophotometer.

\section{Phosphorus Sorption Study}

Phosphate sorption characteristics of the soils were determined by placing eight separate $5 \mathrm{~g}$ sub- samples of the $2 \mathrm{~mm}$ size sieved soils in $50 \mathrm{ml}$ polypropylene centrifuge tubes. Volumes of $40 \mathrm{~cm}^{3}$ of $0.01 \mathrm{M} \mathrm{CaCl}_{2}$ solution containing $0,15,25,40,100,200,400$ and 800 $\mathrm{mg} / \mathrm{l} \mathrm{P}$ as $\mathrm{KH}_{2} \mathrm{PO}_{4}$ were distributed to the tubes as described by (Dear et al., 1992). The samples were then shaken for $24 \mathrm{hrs}$ and then centrifuged for ten minutes at $1200 \mathrm{rpm}$ at $4^{\circ} \mathrm{C}$ in a refrigerated centrifuge. The supernatant was filtered through a Whatman's number 42 filter paper. Phosphorus in solution was determined by a modification of the Murphy and Riley method (Watanabe and Olsen, 1965) and reported by (Page et al., 1982). A plot of $P$ in equilibrium (supernatant) solution was constructed against the amount of $P$ added. For each soil the amount of $P$ that gave the following levels of solution $P$ concentration in the soils $0.025,0.05,0.075,0.100$, $0.125,0.150,0.175,0.200,0.225,0.250 \mathrm{mg} / \mathrm{kg}$, was 
Table 2: Some Properties of the Experimental Soils

\begin{tabular}{|c|c|c|c|c|c|c|c|c|c|c|c|c|c|}
\hline Location & $\begin{array}{c}\mathrm{pH} \\
\left(\mathrm{H}_{2} \mathrm{O}\right)\end{array}$ & $\begin{array}{c}\mathrm{pH} \\
(\mathrm{KCl})\end{array}$ & $\begin{array}{c}\text { Clay } \\
(\%)\end{array}$ & Textur & $\begin{array}{l}\text { O.M } \\
(\%)\end{array}$ & $\begin{array}{c}\text { Tot N } \\
(\%)\end{array}$ & K & $\begin{array}{c}\mathrm{Na} \\
\leftarrow \\
\end{array}$ & $\begin{array}{c}\mathrm{Ca} \\
\mathrm{cmol} / \mathrm{kg}\end{array}$ & Mg & E.acid & $\begin{array}{c}\text { ECEC } \\
\rightarrow\end{array}$ & $\mathrm{Fe}_{2} \mathrm{O}_{3}(\%)$ \\
\hline Abeda & 5.5 & 5.6 & 9 & SCL & 1.07 & 0.03 & 0.24 & 0.12 & 2.00 & 0.78 & 0.01 & 3.14 & 0.6 \\
\hline Otobi & 5.6 & 5.1 & 4 & $\mathrm{~S}$ & 11.03 & 0.05 & 0.47 & 0.13 & 1.67 & 0.73 & 0.02 & 3.11 & 0.4 \\
\hline Tor-donga & 5.9 & 5.3 & 17 & SL & 0.98 & 0.1 & 0.46 & 0.23 & 2.36 & 1.02 & 0.02 & 4.09 & 1.9 \\
\hline Odoba & 5.7 & 4.2 & 12 & LS & 2.0 & 0.3 & 0.37 & 0.14 & 2.64 & 0.93 & 0.02 & 4.11 & 2.8 \\
\hline
\end{tabular}

estimated from these plots. Phosphate sorbed (Ps) was calculated as the difference between the concentration of the added $P$ and the $P$ in solution.

The Freundlich adsorption equation which expresses an empirical relation between the amount of a substance adsorbed $(\mathrm{K})$ per unit mass of the adsorbent $(\mathrm{Q})$ and the aqueous concentration $(C)$ was used to evaluate the adsorption data. The Freundlich equation is given by:

$\log Q=\log K+1 / n \log C$ (Russeland Prescott, 1916), where:

$Q$ is the amount of $P$ adsorbed in $\mathrm{mg} / \mathrm{kg}$

$\mathrm{C}$ is the equilibrium concentration in $\mathrm{mg} / \mathrm{l}$

$\mathrm{K}$ and $\mathrm{n}$ are empirical constants, as $\mathrm{K}$ is a measure of the adsorption capacity.

Phosphorus Buffering Capacity (PBC) was calculated from sorption curves as the slope of the regression equation relating $P$ sorbed to the logarithm of the $P$ concentration of the supernatant solution (Moody et al., 1990; Moody, 2007).

\section{Pot Experiment}

Four $\mathrm{kg}$ of the $2 \mathrm{~mm}$ sieved soil from each location was placed in each of the 33 plastic pots used in the pot study. For each soil the amount of $P$ that was equivalent to the following levels of solution $P$ concentration in the soils; $0.025,0.05,0.075,0.100,0.125,0.150,0.175$, $0.200,0.225,0.250 \mathrm{mg} / \mathrm{kg}$, was added to the pots as $\mathrm{KH}_{2} \mathrm{PO}_{4}$ in $50 \mathrm{~cm}^{3}$ of distilled water and mixed thoroughly. The amounts of $\mathrm{P}$ were estimated for each soil. All the pots initially received equivalents of $60 \mathrm{~kg} \mathrm{~N} / \mathrm{ha}$ as urea, and $30 \mathrm{~kg}$ ha/ $\mathrm{K}$ (Yusuf and Idowu, 2001) as $\mathrm{KCl}$. There were pots without $\mathrm{P}$ addition that served as control bringing the total number of pots to one hundred and thirty two. Three soybean seeds of the variety TGX 1448$2 \mathrm{E}$ were planted per pot and later thinned to two, the pots were laid out in a Randomized Complete Block Design (RCBD) and the crop was grown to maturity with the normal agronomic practices carried out. At harvest (12 WAP), the above ground plant material was dried and weighed. The plant materials were milled and digested in a $4: 1 \mathrm{HNO}_{3}: \mathrm{HClO}_{4}$ mixture and analyzed for $\mathrm{P}$ using the method of (Murphy and Riley, 1962).The optimum solution concentration was determined for each soil both in terms of grain and dry matter yield by subjecting the yield data to the analysis of variance. The critical equilibrium solution $\mathrm{P}$ concentration (SPC) was estimated as the amount of $P$ in an equilibrium concentration needed to achieve maximum yield.

The Standard Phosphate Requirement (SPR) was estimated as the amount of fertilizer $P$ that gave the equilibrium solution concentration required to achieve maximum yield. The quantity of $P$ required to achieve the SPC for each soil was taken as the SPR.

\section{Field Trial}

Field trial was conducted at Otobi, Akpa in Oturkpo local government area of Benue state. The experimental sites was ploughed and harrowed. The size of each treatment plot was $5 \mathrm{~m} \times 5 \mathrm{~m}$ (or $25 \mathrm{~m}^{2}$ ) and each plot was treated with equivalents of $60 \mathrm{~kg} \mathrm{ha}^{-1} \mathrm{~N}$ as Urea, $30 \mathrm{~kg} \mathrm{ha}^{-1} \mathrm{~K}$ as $\mathrm{KCl}$. Phosphate fertilizer quantity that resulted in $0.0,0.5$ SPC, 1.0 SPC and 2.0 SPC (as estimated from the pot experiment) was added per plot as $\mathrm{KH}_{2} \mathrm{PO}_{4}$ and the four treatments were replicated three times in a randomized complete block design (RCBD). Soybean seeds of variety TGX 1448-2E were drilled into the various plots at the rate of $50 \mathrm{~kg} \mathrm{ha}^{-1}$ (Aduayi et al., eds. 2002). Planting was done on the $18^{\text {th }}$ of July, 2010. At harvest, the soybean grains were dried and weighed. Data generated was subjected to analysis of variance and the solution concentration that gave the best yield was taken as the SPC. The solution phosphate concentration (SPC) that gave maximum grain yield was evaluated for each soil and the quantity of $\mathrm{P}$ required (SPR) to achieve this solution concentration was calculated for each soil.

\section{Data Collection}

The following Agronomic data was collected:

Dry matter yield at harvest in both the pot and field experiments, Number of pods per plant, Weight of seeds per pot/plot.

\section{Statistical Analysis}

Data generated in both the pot experiment and field trials was subjected to the analysis of variance. Means were separated using the Duncan multiple range test (DMRT). 
054 Int. Res. J. Agric. Sci. Soil Sci.

Table 3: Selected Phosphorus Fractions of the Experimental Soils ( $\mathrm{mg} / \mathrm{kg}$ )

\begin{tabular}{lccccccc}
\hline Location & Total $\mathbf{P}$ & Organic $\mathbf{P}$ & Fe-P & Al-P & Ca-P & Bray-1P & Olsen-P \\
\hline Abeda & 276.8 & 132.9 & 62.82 & 41.88 & 28.3 & 2.0 & 3.6 \\
Otobi & 296.1 & 139.3 & 73.1 & 46.2 & 31.5 & 3.7 & 2.3 \\
T/donga & 298.3 & 143.2 & 112.8 & 22.3 & 11.6 & 3.8 & 4.6 \\
Odoba & 215.3 & 103.3 & 90.2 & 9.0 & 12.8 & 2.1 & 6.4 \\
\hline
\end{tabular}

Table 4: Sorption parameters and yield of soybean on the Soils in the pot experiment

\begin{tabular}{lcccccccc}
\hline S/NO & LOCATION & $\begin{array}{c}\text { SPC } \\
(\mathbf{m g} / \mathbf{k g})\end{array}$ & $\begin{array}{c}\text { SPR } \\
(\mathbf{g} / \mathbf{k g})\end{array}$ & $\begin{array}{c}\text { PBC } \\
(\mathbf{m g} / \mathbf{k g})\end{array}$ & $\mathbf{K}$ & Pod No & $\begin{array}{c}\text { Seed wt } \\
(\mathbf{g} / \mathbf{p o t})\end{array}$ & $\begin{array}{c}\text { DMY } \\
(\mathbf{g} / \mathbf{p o t})\end{array}$ \\
\hline 1 & ABEDA & 0.025 & 0.83 & 100.30 & 9.3 & 54.3 & 15.12 & 8.5 \\
2 & OTOBI & 0.025 & 0.26 & 121.7 & 21.0 & 53.0 & 22.3 & 16.3 \\
3 & T/DONGA & 0.10 & 0.88 & 39.51 & 18.0 & 59.3 & 9.7 & 13.9 \\
4 & ODOBA & 0.10 & 4.74 & 36.58 & 16.2 & 48.7 & 12.7 & 8.2 \\
\hline
\end{tabular}

Correlation analysis was carried out to determine the relationship between the studied (sorption) parameters and some soil properties. Regression analysis was carried out to study the relationship between the $P$ sorbed and the logarithm of $P$ concentration in the supernatant solution in the laboratory experiment. The SAS statistical package was used for these analyses.

\section{RESULTS AND DISCUSSION}

\section{Physical and Chemical Properties of the Soils}

Some selected properties of the soils are shown on Table 3. The soils are acid ranging in $\mathrm{pH}\left(\mathrm{H}_{2} \mathrm{O}\right)$ from 5.5 at Abeda-Mbadyul to 5.9 at Tor-Donga. Clay content was also variable and ranged from $4 \%$ at Otobi, Akpa to $17 \%$ at Tor-Donga. The soils are sand, sandy loam, loamy sand and sandy clay loam in texture. Soil organic matter status ranged from $0.98 \%$ at Tor-Donga to $11.03 \%$ at Otobi. Total nitrogen values were low and varied from $0.03 \%$ at Abeda- Mbadyul to $0.3 \%$ at Odoba. Response to applied nutrients was thus probable. Iron oxide content was least at Otobi with a value of $0.4 \%$ while the highest value of $2.8 \%$ was found at Odoba, the aluminium oxide content was least at Abeda-Mbadyul with a value of $0.8 \%$ and highest at Odoba with a value of $1.3 \%$.

Selected $P$ fractions of the experimental soils are shown on Table 4. The total $P$ varied from $215.3 \mathrm{mg} / \mathrm{kg}$ at Odoba to $298.3 \mathrm{mg} / \mathrm{kg}$ at Tor-Donga. Organic $P$ values followed the same trend with the least value of 103.3 $\mathrm{mg} / \mathrm{kg}$ at Odoba to $143.2 \mathrm{mg} / \mathrm{kg}$ at Tor-Donga and constituted about $47.74 \%$ of total P. The Fe-P content was variable and ranged from73.1 mg/kg at Otobi, Akpa to $112.8 \mathrm{mg} / \mathrm{kg}$ at Tor-Donga and constituted about $31.19 \%$ of total P. Al-P varied from $9.0 \mathrm{mg} / \mathrm{kg}$ at Odoba to $41.88 \mathrm{mg} / \mathrm{kg}$ at Abeda and constituted about $10.99 \%$ of the total, while the Ca-P varied from $11.6 \mathrm{mg} \mathrm{kg}^{-1}$ at TorDonga to $31.5 \mathrm{mg} \mathrm{kg}^{-1}$ at Otobi, Akpa and constituted about $7.75 \%$.

Bray-1P was highest at Tor-Donga $\left(3.8 \mathrm{mg} \mathrm{kg}^{-1}\right)$ while the least value of $2.0 \mathrm{mg} \mathrm{kg}^{-1}$ was recorded at AbedaMbadyul with an average value of $2.9 \mathrm{mg} \mathrm{kg}^{-1}$, Olsen $\mathrm{P}$ was highest at Odoba $\left(6.4 \mathrm{mg} \mathrm{kg}^{-1}\right)$ and the least value of $2.3 \mathrm{mg} \mathrm{kg}^{-1}$ was recorded at Otobi, Akpa.

\section{Effect of Solution $P$ Concentration on Yield Parameters in the Field Experiment}

Table 5 shows the effect of solution $\mathrm{P}$ concentration on yield parameters from the field trial at Otobi. $15.967 \mathrm{~kg}$ per plot was obtained with a solution concentration of 2.0 SPC in terms of seed weight this was equivalent to $6386.8 \mathrm{~kg}$ (6.4 tons) per hectare and was significantly higher than all the other treatments. 1.0 SPC followed and produced $12.65 \mathrm{~kg}$ per plot which was equivalent to $5060 \mathrm{~kg}$ (5.01 tons) per hectare and differs significantly from the others. The 0.5 SPC and the control, (0.0 SPC) treatment were significantly not different from each other but were significantly lower than the other levels. In terms of dry matter yield, there was no significant difference between the 2.0 SPC and the 1.0 SPC treatments though the values obtained here were significantly different from both the 0.5 SPC and the control, (0.0 SPC) treatment that did not differ significantly from each other. Significant differences were observed across the treatments in terms of one hundred seed weight. The highest seed weight was obtained at a solution concentration that was twice the SPC in the field trial indicating that the SPC could have been higher than the value of $0.025 \mathrm{mg} \mathrm{kg}^{-1}$ estimated from the pot experiment. Generally, the variation in terms of the SPC between the pot experiment and the field was little. Dear et al., (1992) had earlier 
Table 5: Correlation coefficients $(r)$ between sorption parameters and soil properties in the Inceptisols

\begin{tabular}{|c|c|c|c|c|c|c|c|c|c|c|c|c|c|c|c|}
\hline SPC & SPR & PBC & K & $\mathrm{pH}$ & Clay & O.M & $\mathrm{Fe}_{2} \mathrm{O}_{3}$ & $\mathrm{Al}_{2} \mathrm{O}_{3}$ & Total P & Org.P & FeP & AIP & $\mathrm{CaP}$ & Bray & Olsen \\
\hline SPC & & & & & & & & & & & & & & & \\
\hline SPR & 0.635 & & & & & & & & & & & & & & \\
\hline PBC & $-0.979^{*}$ & -0.665 & & & & & & & & & & & & & \\
\hline $\mathrm{K}$ & 0.219 & -0.081 & -0.014 & & & & & & & & & & & & \\
\hline $\mathrm{pH}$ & 0.845 & 0.144 & -0.765 & 0.485 & & & & & & & & & & & \\
\hline Clay & 0.900 & 0.887 & -0.934 & -0.063 & 0.527 & & & & & & & & & & \\
\hline O.M & -0.541 & -0.373 & 0.697 & 0.676 & -0.299 & -0.632 & & & & & & & & & \\
\hline $\mathrm{Fe}_{2} \mathrm{O}_{3}$ & 0.151 & -0.381 & 0.039 & 0.929 & 0.570 & -0.235 & 0.590 & & & & & & & & \\
\hline $\mathrm{Al}_{2} \mathrm{O}_{3}$ & $0.970^{*}$ & 0.727 & -0.920 & 0.353 & 0.779 & 0.902 & -0.367 & 0.207 & & & & & & & \\
\hline TotalP & -0.409 & $-0.965^{\star}$ & 0.455 & 0.181 & 0.119 & -0.743 & 0.265 & 0.510 & -0.527 & & & & & & \\
\hline Org.P & -0.409 & $-0.965^{\star}$ & 0.455 & 0.181 & 0.119 & -0.743 & 0.265 & 0.510 & -0.527 & $1.000^{* *}$ & & & & & \\
\hline $\mathrm{FeP}$ & 0.787 & 0.023 & -0.729 & 0.374 & $0.983^{*}$ & 0.452 & -0.380 & 0.521 & 0.679 & 0.241 & .241 & & & & \\
\hline AIP & -0.944 & -0.850 & $0.954^{*}$ & -0.063 & -0.624 & $-0.991^{\star *}$ & 0.570 & 0.100 & $-0.952^{*}$ & 0.683 & 0.683 & -0.542 & & & \\
\hline $\mathrm{CaP}$ & $-0.991^{\star *}$ & -0.607 & $0.994^{\star *}$ & -0.102 & -0.830 & -0.900 & 0.647 & -0.065 & -0.931 & 0.381 & 0.381 & -0.794 & 0.934 & & \\
\hline Bray & -0.383 & 0.569 & 0.561 & 0.803 & .027 & -0.644 & 0.913 & 0.837 & -0.273 & 0.551 & 0.551 & -0.019 & 0.544 & 0.476 & \\
\hline Olsen & 0.852 & .900 & -0.908 & -0.172 & 0.443 & $0.993^{* *}$ & -0.681 & -0.345 & 0.846 & -0.776 & -0.776 & 0.376 & $-0.968^{*}$ & -0.862 & -0.721 \\
\hline
\end{tabular}

* Significant at $1 \% \quad$ ** significant at $5 \%$

reported little variations between the EPC in the green house and that of field. These results show the greater importance of buffer capacity in the field, reflecting the fact that a plant root system will explore a given volume of soil much less effectively in the field than in the pot and are therefore more sensitive to variations in buffer capacity under field conditions Holford, (1980). These variations were attributed to the more favorable moisture conditions prevailing in the green house which could be expected to increase the diffusion of $P$ to the root hairs and lower the optimum level of solution $\mathrm{P}$ required (Adetunji, 1995). Thus the critical value determined under the green house conditions could also be applied to the field situation when similar laboratory procedures and the same crops are used.

\section{Relationships between Sorption Parameters} and Soil Properties in the Experimental Soils

The relationship between the PBC and SPC of the Inceptisols was negative but significant $(r=$ 0.979 ) while the oxides of aluminum showed a positive and significant relationship with the SPC $(r=0.970)$ (Table 6). Total $P$ as well as the organic $P$ fractions related negatively and significantly with the SPR $(r=-0.965)$. The iron $P$ fraction related positively and significantly with soil $\mathrm{pH}(\mathrm{r}=0.983)$ while the aluminum $P$ fraction showed a positive and significant relationship with the PBC ( $r=$ 0.954 ) and related negatively and highly significantly with the clay content $(r=-0.991)$ and negatively and significantly with the aluminum oxide content of the soils $(r=-0.952)$. The relationship between the calcium $\mathrm{P}$ fraction and the SPC was negative and highly significant $(r=$ 0.994). Olsen $P$ related positively and highly significantly with clay content $(r=0.993)$ but showed a negative and significant relationship with the aluminum P fraction. (Agbenin, 2003) had earlier reported evidence that clay mineral and extractable oxides of $\mathrm{Fe}$ and Al play an important role in $\mathrm{P}$ fixation in soils. In the same way, (Wiriyakitnateekul et al., 2005) reported that in Thai soils, $81 \%$ of variability in $\mathrm{P}$ sorption was related with extractable $\mathrm{Fe}$ and $\mathrm{Al}$ by dithionate and oxalate extraction. Also, (Maguire et al., 2001) reported that sorption of $P$ was strongly correlated with the amounts of $\mathrm{Al}$ and $\mathrm{Fe}$. In addition, (Wang et al., 2001) mentioned that many soils with high $\mathrm{P}$ retention were related to high 
056 Int. Res. J. Agric. Sci. Soil Sci.

Table 6: Correlation Coefficients between Soil Properties and Yield Parameters

\begin{tabular}{|c|c|c|c|c|}
\hline & $\mathrm{P}$ biomass & Pod No. & Seedwt. & DMY \\
\hline $\mathrm{pH}$ & 0.241 & 0.31 & 0.218 & 0.379 \\
\hline Clay & 0.55 & $-0.602^{*}$ & $-0.650^{*}$ & $-0.658^{*}$ \\
\hline $\mathrm{Fe}-\mathrm{P}$ & $0.587^{*}$ & 0.045 & $-0.579^{*}$ & -0.023 \\
\hline Al-P & 0.31 & 0.077 & 0.145 & 0.085 \\
\hline Ca-P & -0.278 & $0.633^{*}$ & $0.687^{\star}$ & $0.755^{\star *}$ \\
\hline Bray-1P & -0.257 & 0.538 & 0.439 & $0.736^{\star *}$ \\
\hline Olsen-p & 0.453 & -0.025 & -0.266 & -0.258 \\
\hline
\end{tabular}

levels of oxalate extractable $\mathrm{Fe}$ and $\mathrm{Al}$.

\section{Relationship between Soil Properties, Sorption and Yield Parameters in the Soils}

Correlation coefficients between the properties of the experimental soils and the yield parameters studied are shown on Table 6. Clay content showed negative and significant relationships with the pod number, seed weight and the dry matter yield $(r=-0.602,-0.650$ and $0.658)$ respectively. The relationship between the iron $P$ fraction and the total $P$ in plant biomass was positive and significant $(r=0.587)$ while that with the seed weight was negative and significant $(r=-0.579)$. There was no significant relationship between the aluminum $P$ fraction and any of the yield parameters but the calcium $P$ fraction showed significant and positive relationships with the pod number and seed weight. $(r=0.633$ and 0.687$)$. The relationship with the dry matter yield was positive and highly significant $(r=0.755)$. Bray $-1 \mathrm{P}$ also showed a positive and highly significant relationship with the dry matter yield $(r=0.736)$.

The positive and significant relationship between the PBC and the seed weight of the soybean crop indicate that soils that are well buffered will be more preferable for the production of soybean as such soils will have the ability to provide a sustained amount of $P$ in the soil solution for the utilization of the crop throughout the growing season. This can be so achieved because of the ability of such soils to release labile $P$ held loosely on the solid phase to $P$ in the soil solution at levels optimal enough to sustain maximum yield as $P$ is removed from solution by crop uptake. The case of Vanam, Abaji- Kpav, Abeda- Mbadyul and Otobi in the experimental soils readily comes to mind.

Bray-1P related positively and significantly with the dry matter yield. This show that bray-1 extractant was able to extract only that portion of soil $\mathrm{P}$ that was utilized by the plants from the soils. The Olsen extractant with higher $P$ values did not correlate any of the yield parameters indicating that this extractant could have as well removed not only the plant available $\mathrm{P}$ but other forms of soil $\mathrm{P}$ that ordinarily are not available to the growing plant. Also since all the soils used in the study were acidic, the Olsen extractant which is sodium hydrogen carbonate $\left(\mathrm{NaHCO}_{3}\right)$ buffered at $\mathrm{pH} 8.5$ could have been neutralized easily by the acidic nature of the soils. Holford $\left(1980^{b}\right)$ reported that acidic lactate or fluoride have been found most effective on a wide range of soils, except calcareous soils which neutralize the acidic component (usually hydrochloric or acetic acid) of the extractant. Sodium bicarbonate (pH 8.5) has been found effective on calcareous soils and is widely used throughout the world. Bray-1P can thus be referred to as the plant available $\mathrm{P}$ in these soils. Similar performance by bray-1 had earlier been reported in southwestern Nigeria by (Adetunji, 1995).

\section{CONCLUSION}

The highly significant and negative relationship between the Ca-P fraction and the SPC $(r=-0.991)$ of the Inceptisols indicate that this $\mathrm{P}$ fraction will diminish as the SPC increases. The highly significant and positive relationship with the PBC $(r=0.994)$ shows that this $P$ fraction could be held loosely on the soil solid phase and would be easily released into solution. As $P$ is added to soils, the Ca-P fraction would again revert to the solid phase $\mathrm{P}$. The Ca-P fraction thus is a component of the labile $\mathrm{P}$ pool in acid soils. It was concluded that buffering capacity plays an important role in $\mathrm{P}$ uptake, yield of soybean as well as the solution $\mathrm{P}$ concentration required to achieve optimum yield. Integration of sorption influenced indices such as quantity, intensity and buffering capacity in the measurement of $P$ availability and $\mathrm{P}$ fertilizer

requirement of these soils would improve the accuracy of $P$ fertilizer recommendations. Usually, these indices are expressed by a combination of two or more parameters since they are interdependent. These parameters include the solution $\mathrm{P}$ concentration (SPC), which is defined as the optimum solution $\mathrm{P}$ concentration required to achieve 95\% maximum crop yield; the standard $P$ requirement (SPR) which is the quantity of fertilizer $P$ required to 
attain the SPC; and the P buffering capacity (PBC) which expresses the dynamic relationship between solid and solution phase $P$.

\section{REFERENCES}

Adepetu JA (1981). Characteristics Phosphorus sorption and its implications in soils of Ondo State of Nigeria. Wasitr. Trop. Landwritsch Veterinaemed 19: 291-300

Adepoju A.Y (1993). Evaluation of $P$ sorption capacity of forest and savannah soils of Nigeria. Tropical Agric. (Trinidad) 70: 127-130

Adetunji MT (1995). Equilibrium phosphate concentration as an estimate of phosphate needs of maize in some tropical Alfisols. $J$. tropical Agric.(Trinidad) 72:285-289

Aduayi EA, ChudeVO, Adebusuyi BA, Olayiwola SO (2002). Fertilizer use and management practices for crops in Nigeria. $3^{\text {rd }}$ ed. S.B.Garko intel. limited. 67-70.

Agbenin JO (2003). Extractable iron and aluminium effects on phosphate sorption in a savannah Alfisol. Soil Sci. Society of America J. 67:589-595

Anyaduba ET, Adepetu JA (1983) Predicting the Phosphorus fertilization need of tropical soils; significance of the relationship between critical solution $\mathrm{P}$ requirement of cowpea, $\mathrm{P}$ sorption potential and free iron con tent of soils. J. tropical Agric. and Veterinary Sci. 21: (1)21-30

Bouyoucos GH (1951). A recalibration of the hydrometer method for testing mechanical analysis of soils. Agronomy J. 43:434-438

Bra RH, Kutz LT (1945). Determination of total, Organic and Available forms of phosphorus in soils. Soil Sci., 59:45-59

Chang SC, Jackson ML (1957). Fractionation of soil phosphorus. Soil sci. 84: $133-144$

Dalal RC, Hallsworth BG (1976). Evaluation of the parameters of soil phosphorus availability factors in predicting yield response and phosphorus uptake. Soil sci. Society of America J. 40: 541-546

Dear BS, Helyar, KR, Muller WJ, Loveland B (1992). The P fertilizer requirements of subterranean clover, and the soil $\mathrm{P}$ status, sorption and buffering capacities from two P analyses, Australian J. Soil Res. 30: $27-44$

Federal Department of Agricultural Land Resources (1990). Soils Report: IV: 76-132

Holford ICR (1980). Effects of phosphate buffer capacity on critical levels and relationships between soil tests and labile phosphate in wheat growing soils. Aust. J. soil res. 18: 405-14
Maguire RO, Foy RH, JS, Bailey, Sims JT (2001). Estimation of the Manag. 17:12-20.

Mebra OP, Jackson MI (1960). Iron oxide removal from soils and clays by a dithionate-citrate system buffered with sodium bi carbonate. Proceedings of $7^{\text {th }}$ National Conference on clays and clay minerals pp 317-327.Peragon press, New York.

Mehra NO, Legg JC, Goring CAl, Black CA (1954). Determination of organic phosphorus in soils: 1. Extraction methods. Soil Sci. Society of America Proceedings 18: 443-449

Moody PW, Dickson T, Dwyer JC, Compton BL (1990). Predicting yield responsiveness and phosphorus fertilizer requirement of soybeans from soil tests. Australian J. Soil Res 28: 399-406.

Moody PW (2007). Interpretation of a single point $P$ buffering index for adjusting critical levels of the Cowell soil P test. Australian J. soil research 45:55-62.

Murphy J, Riley JP (1962). A modified single solution method for determination of phosphorus in natural waters. Anal. Chem..Acta. 27:31-36

Olsen SR, Cole LT, Watanabe FS, Dean LA (1954). Estimation of available phosphorus in soils by extraction with sodium bicarbonate. U. S Department of Agric. circ. 939

Page AL, Miler RH, DR Keeney (eds) (1982). Methods of soil analysis, part 2, Chemical and Microbiological properties $2^{\text {nd }}$ edition, Agronomy 9: Soil Science Society of America. Madison, USA.

Peterson, G.W and R. B. Corey (1966).A modified Chang and Jackson procedure for routine fractionation of inorganic soil phosphorus. Soil Science Society of America proceedings 30: 563-565

Russel EG, Prescott JA (1916). The reaction between dilute acids and the phosphorus compounds of the soil. J. Agric. Sci. Camb. 8: 65110

Walkley A, Black IA (1934). An examination of Degtjareff method for determining soil organic matter and proposed modification of the chromic acid in soil analysis.1. Experimental soil sci. 79: 459-465.

Wang X, Jackman JM, Yost RS, Linguist BA (2001). Predicting soil phosphorus buffer coefficients using potential sorption site density and soil aggregation. Soil Sci. Society of America J. 64: 240-246

Watanabe FS, Olsen SR (1965). Test of an ascorbic acid method for determination of phosphorus in water and $\mathrm{NaHCO}_{3}$ extracts from soils. Soil Science Society of America proceedings 29: 677

Wiriyakitnateekul W, Suddhiprakarn A, Kheuruenromne I (2005). Extractable iron and aluminium predict the $\mathrm{P}$ sorption capacity of Thai soils. Australian J. soil res. 43:757-766

Yusuf IA, Idowu AA (2001). NPK requirement for soybean production in the Southern Guinea Savannah. Trop. oil seeds J. 6:50-56. 